\title{
Design and Simulation of MPPT Control Strategy for Solar PV by Using Fuzzy Control
}

\author{
Abhishek Verma ${ }^{1}$, Brahma Nand Thakur ${ }^{2}$, Dr. Abhishek Verma ${ }^{3}$,Dr. Anup Mishra ${ }^{4}$, \\ , Dr. Ashish Kumar Tamrakar ${ }^{5}$, \\ PG Student, Dept. of EEE, Bhilai Institute of technology, Durg, Chhattisgarh, India ${ }^{1}$ \\ Assistant professor, Dept. of EEE, Bhilai Institute of technology, Durg, Chhattisgarh, India ${ }^{2}$ \\ Associate professor, Dept. of EEE, Bhilai Institute of technology, Durg, Chhattisgarh, India ${ }^{3}$ \\ Head Of department, Dept. of EEE, Bhilai Institute of technology, Durg, Chhattisgarh, India ${ }^{4}$ \\ Assistant professor, Dept of CS, RCST,Durg Chhattisgarh, India ${ }^{5}$ \\ abhishekverma3421@gmail.com ${ }^{1}$, brahmanand.thakur@bitdurg.ac.in², \\ abhishek.verma@bitdurg.ac.in ${ }^{3}$, \\ anupmishra.bit123@gmail.com ${ }^{4}$, ashish.tamrakar1987@gmail.com ${ }^{5}$
}

\begin{abstract}
This Paper presents the simulation of a solar PV module with a maximum power point tracking algorithm using fuzzy logic controller.MPPT can be done by using various methods like PI control and perturbation and observation method. For increasing the efficiency of solar PV it is necessary. Different methods are available to generate maximum power in different weather conditions. This model contains a PV module with DC-DC boost converter. The Fuzzy logic based is proposed in this method to increase the voltage PV module. The proposed method use the fuzzy logic control to initiate the control command of boost converter. . This work is all about the design of a control system to retrieve maximum output from the radiations and to get a better power quality without any harmonics and distortions. The PV system is developed and simulated with the help of MATLAB/ Simulink software environment.
\end{abstract}

KEYWORDS: Maximum power point tracking system (MPPT), Pulse Width Modulation (PWM), Insulated gate bipolar transistor (IGBT), Total harmonic distortion (THD), static synchronous compensator (STATCOM),), and fuzzy logic control (FLC)

\section{INTRODUCTION}

With the modern lifestyles and the fast growth in industries the energy supply and demand chain has been subjected to remarkable strain. In addition, the issues of climate change and the need to diminish carbon footprints have added to the strong thrust for companies and nations to invest in alternate energy sources, particularly the renewable energy (RE) resources. Among the available RE resources, SPV source has emerged as one of the finest green energy resource and seen as a better replacement for conventional energy. The contribution of the energy harvested through the SPV systems had been significant in the past decade in meeting the national as well as international energy demands. In addition, the enhanced scale and eco-friendly nature of solar energy have attracted many researchers to propose scholarly research in this area. [1]

\begin{abstract}
While massive amount of work has been carried out to improve the array configuration and parameter evaluation, equal importance has also been given to improve the power yield efficiency of PV system by improving its maximum power point tracking (MPPT) competence. MPPT is one of the most cost-effective ways to improve the overall PV system efficiency. Also MPPT improves the operating lifetime of the PV system. In the conventional MPPT techniques, the power is calculated at any instant by sensing the voltage and current of the PV array and accordingly the duty cycle of the converter is adjusted to match the maximum power point. Depending upon the environmental conditions the location of the maximum power point (MPP) changes and is not known a priori, but can be located by calculation models or by search algorithms. The purpose or the role of various algorithms is to control the duty cycle (D) of the converter used. This is done in such a manner that the actual load line as seen by the PV array coincides with that of a load at which maximum power in extracted from the panel.[2]
\end{abstract}

\section{MODELLING OF SOLAR PV}


The electrical equivalent circuit or the electrical model of the solar cell shown in figure 1.

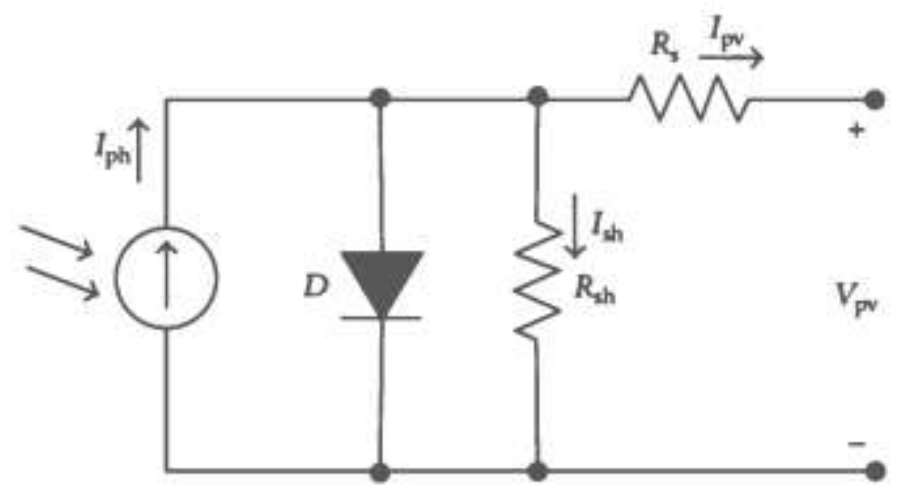

Fig. 1 Equivalent circuit of solar cell

The characteristic equation of the solar PV cell is expressed by,

$I_{p v}=I_{l}-I_{0}\left(e^{\frac{q\left(V_{p v-I} I_{r s}\right)}{A K T}-1}\right)-\frac{V-R_{S}}{R_{s h}}$

where I and $\mathrm{V}$ are the solar cell output current and voltage respectively, Io is the saturation current, charge of an electron is taken as q, A is the ideality factor of diode, $\mathrm{k}$ is the Boltzmann constant, $\mathrm{T}$ - temperature at absolute condition and $R S$ and $R S H$ are the series and shunt resistances of the solar photo voltaic cell. In an ideal case $R S$ would be zero and $R S H$ infinite. A typical PV panel is composed of many solar cells, which are connected in series and parallel so that the output current and voltage of the PV panel are high enough to the requirements of the applications under consideration. The output current-voltage characteristic of a PV panel is expressed by equation (2), where np and ns are the number of solar cells in parallel and series respectively.

$I \approx n_{p} I_{l}-n_{p} I_{0}\left(e^{\frac{q\left(V_{-} I_{r s}\right)}{A K T n_{s}}-1}\right)$

\section{PV ARRAY CHARACTERISTIC CURVE}

The current to voltage characteristics of solar PV is nonlinear. Therefore it is difficult to determine the maximum power point. The below figure gives I-V and P-V curve for solar irradiation

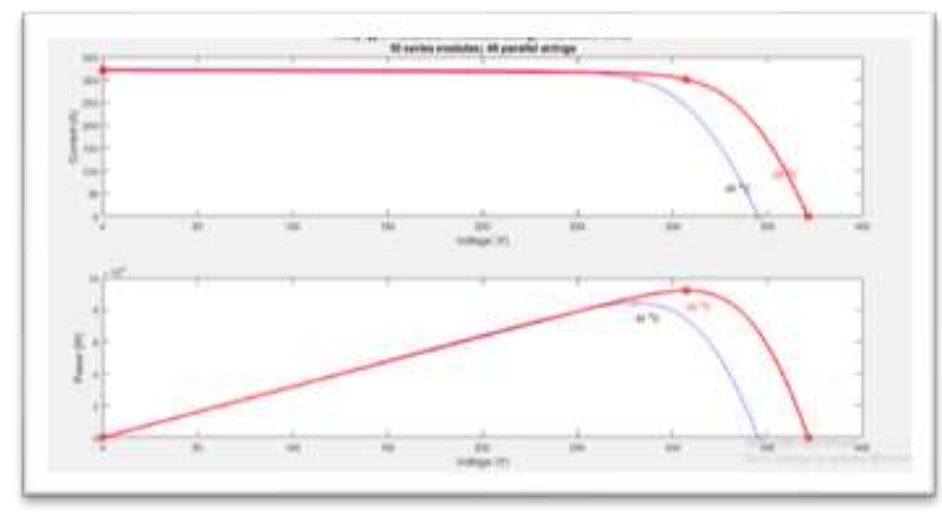

Fig -2: I-V and P-V Characteristics 


\section{BOOST CONVERTER}

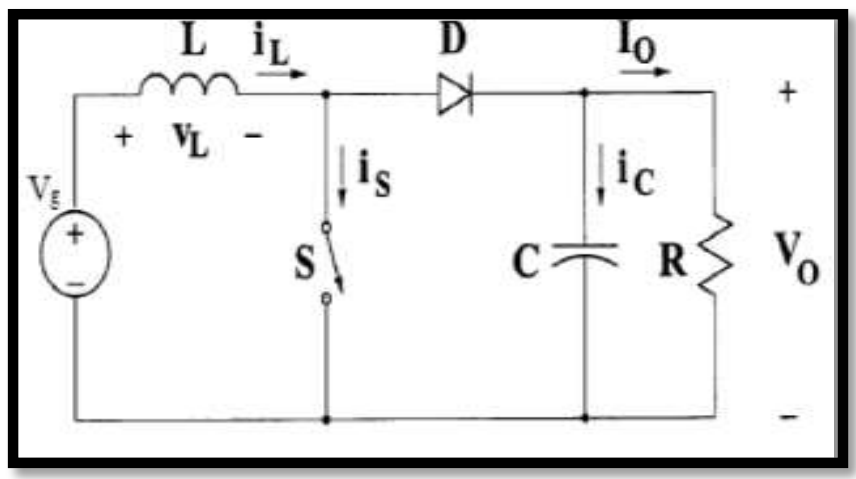

Fig -3: Boost Converter

The Fig.3 shows a step up or PWM boost converter. It consists of a dc input voltage source Vg; boost inductor L, controlled switch $\mathrm{S}$, diode $\mathrm{D}$, filter capacitor $\mathrm{C}$, and the load resistance $\mathrm{R}$. When the switch $\mathrm{S}$ is in the on state, the current in the boost inductor increases linearly and the diode $\mathrm{D}$ is off at that time. When the switch $\mathrm{S}$ is turned off, the energy stored in the inductor is released through the diode to the output RC circuit. In this way we get the desired output voltage by this boost converter. We can easily regulate its output voltage by varying the output resistance.

$V_{\text {out }}=\frac{1}{1-D} V_{\text {in }}$

$R_{p v}=(1-D) 2 R_{\text {out }}$

\section{Maximum Power Point Tracking}

Solar radiation that incident on PV modules depends upon the geographical latitude and orientation of the field, the season and hour of the day. During the whole day shadow may be cast on the cell that may be foreseen as in the case of a building near the solar field and many kind of shadows that may be due to clouds, birds or some other construction that covers the sunrays during some certain hours of the day. The energy produced by each PV cell depends upon the irradiation and temperature according to all these consideration it is necessary that to identify the point instant by instant that particular point on the V-I characteristics in which there is the possibility of the maximum amount of power being transferred to the grid or load. This maximum power point keeps shifting its position according to the climate or environmental condition change. So MPPT becomes an integral part of solar PV system. The function of this controller is to adjust the resistance as seen by the panel and operates the Maximum power point. Also it alters the duty cycle of the DC-DC converter so as to match output voltage of the PV generators with the battery voltage.

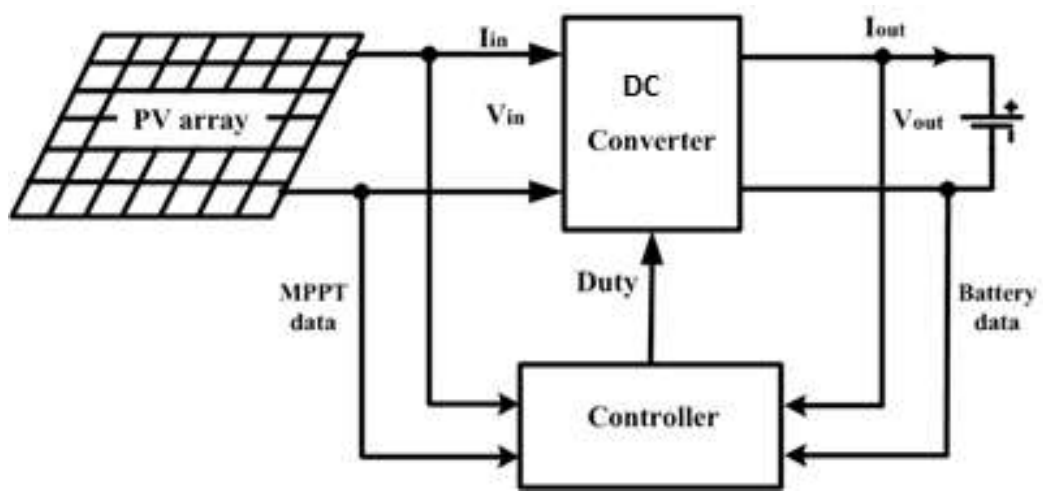

Fig -4: DC-DC converter with MPPT controller 


\section{FUZZY CONTROL SYSTEM}

MPPT using fuzzy control method is more popular now a days. The block diagram of fuzzy logic algorithm is shown in figure below. These controllers are independent of the process model. Fuzzy systems are based on fuzzy set theory and its associated techniques and rules. Basically rules can be designed according to the situation so as to get the desired outputs and results.

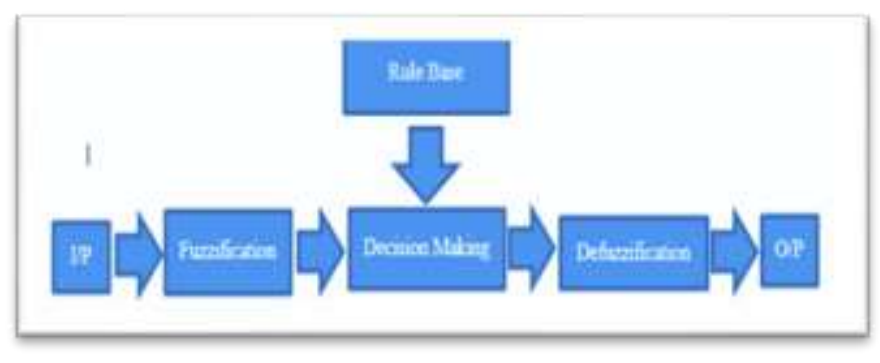

Fig -5: Block diagram of fuzzy logic control

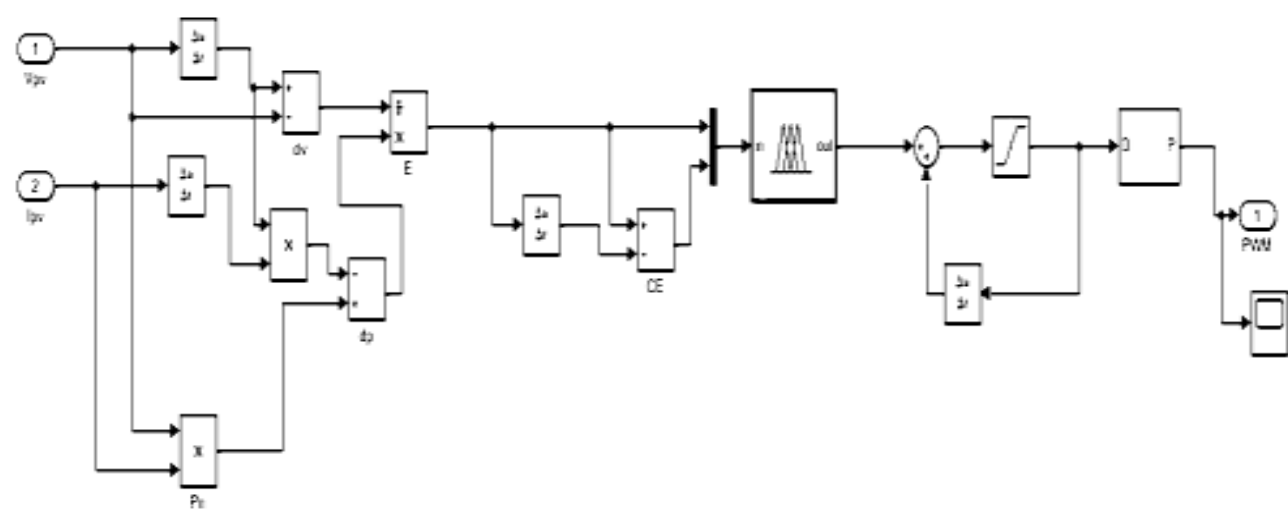

Fig -6: MPPT based on fuzzy logic system

\begin{tabular}{|l|l|l|l|l|l|l|}
\hline E & dE & NB & NS & ZE & PS & PB \\
\hline & NB & ZE & ZE & PB & PB & PB \\
\hline & NS & ZE & ZE & PS & PS & PS \\
\hline & ZE & PS & ZE & ZE & ZE & NS \\
\hline & PS & NS & NS & NS & ZE & ZE \\
\hline & PB & NB & NB & NB & ZE & ZE \\
\hline
\end{tabular}

Table 1 Fuzzy Rules 


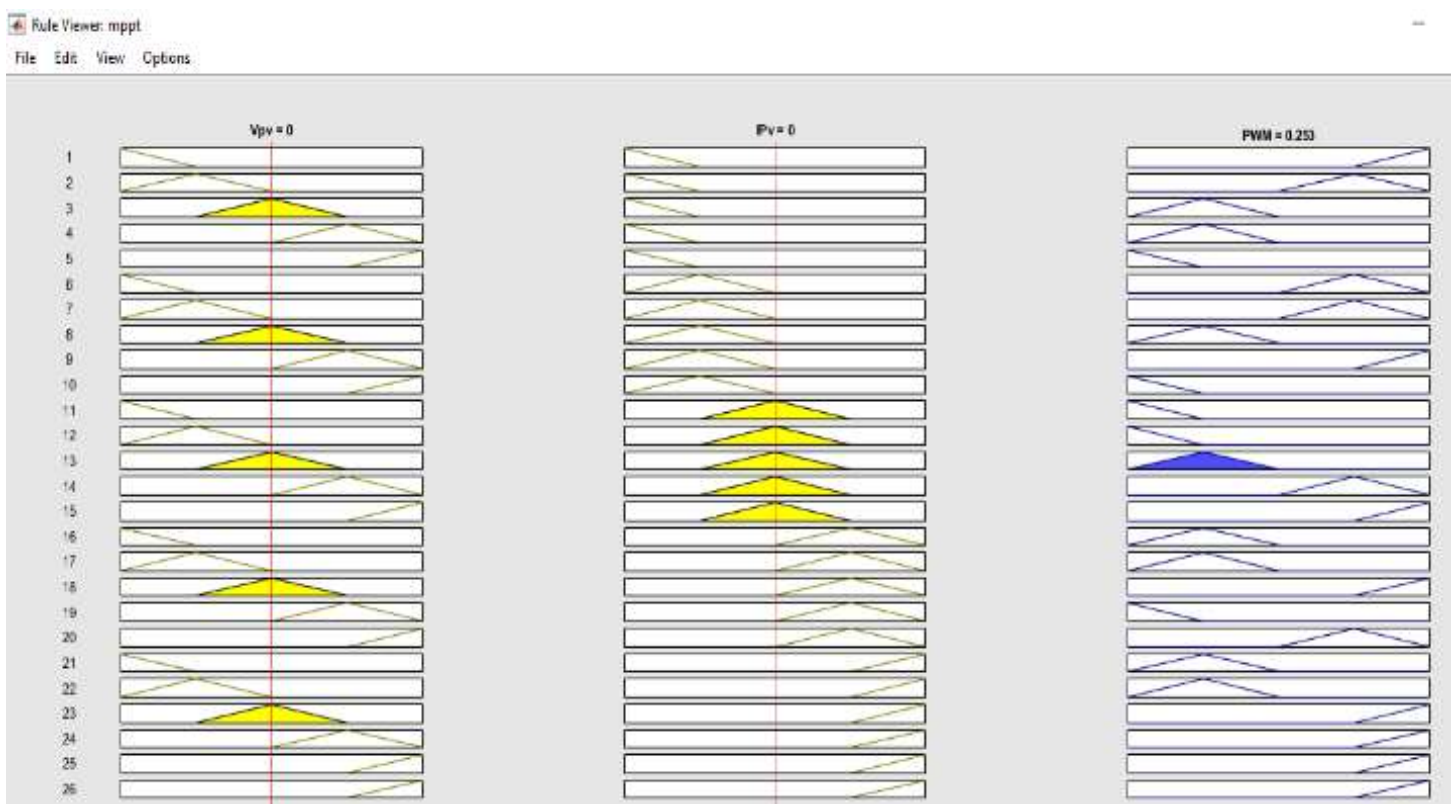

Fig -7: Rule view

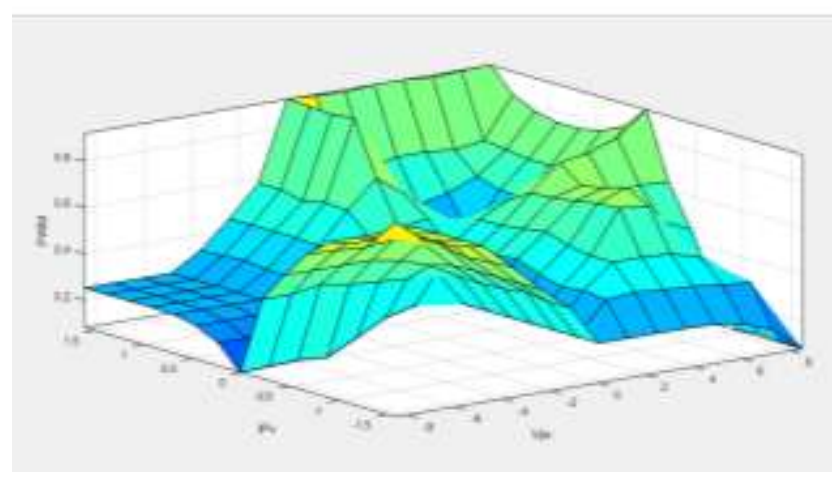

Fig -8: Surface view

\begin{tabular}{|l|l|}
\hline \multicolumn{2}{|c|}{ Parameters } \\
\hline $\begin{array}{l}\text { Solar PV open circuit } \\
\text { voltage }\end{array}$ & $37.14 \mathrm{~V}$ \\
\hline Short Circuit Current & $8 \mathrm{~A}$ \\
\hline Resistance & $50 \Omega$ \\
\hline Inductance & $350 \mu \mathrm{H}$ \\
\hline Capacitance & $560 \mu \mathrm{F}$ \\
\hline
\end{tabular}

Table 2 Parameters Used 


\section{RESULT AND DISCUSSION}

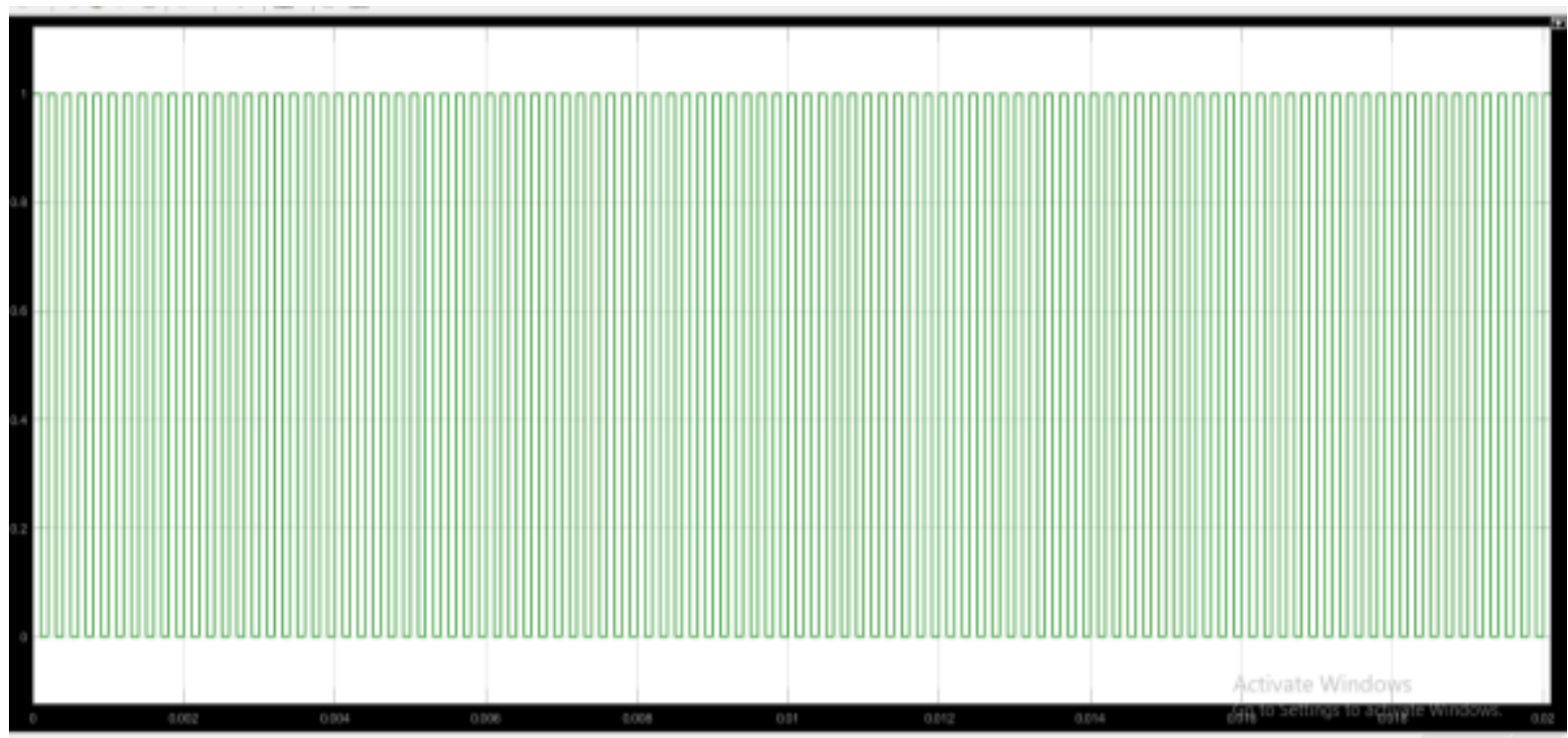

Fig -9: PWM Pulses

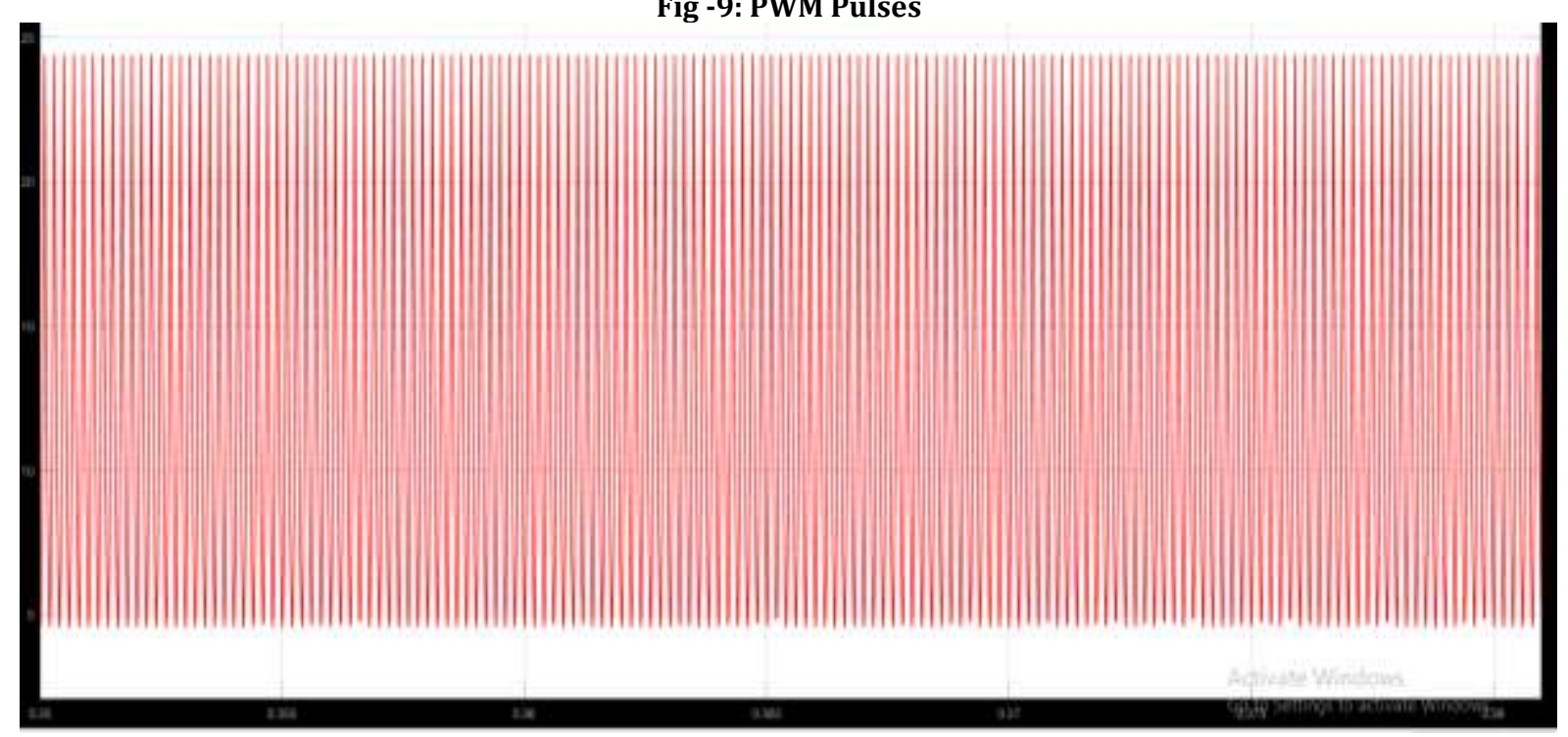

Fig -10: Power in boost converter

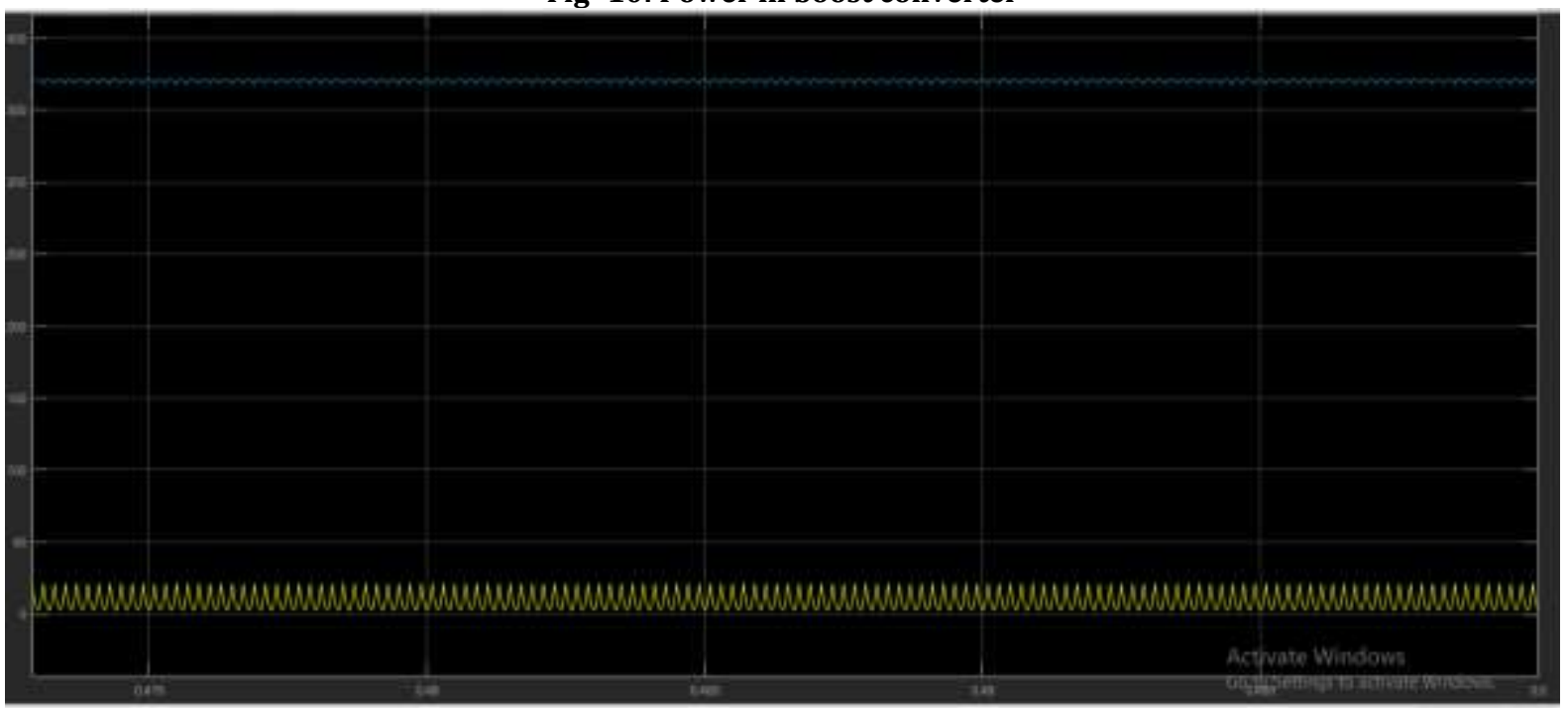

Fig -11: Voltage and current 


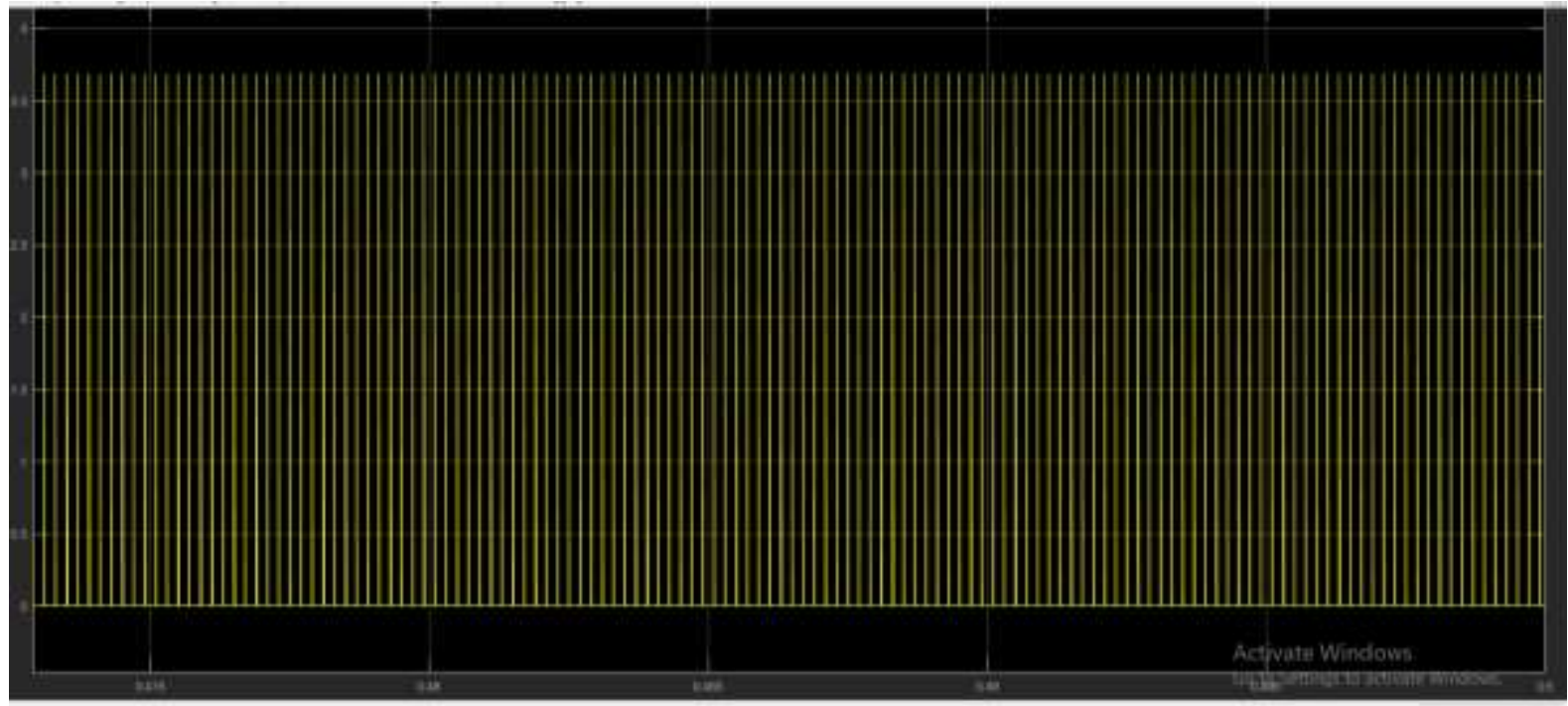

Fig -12: DC link voltage

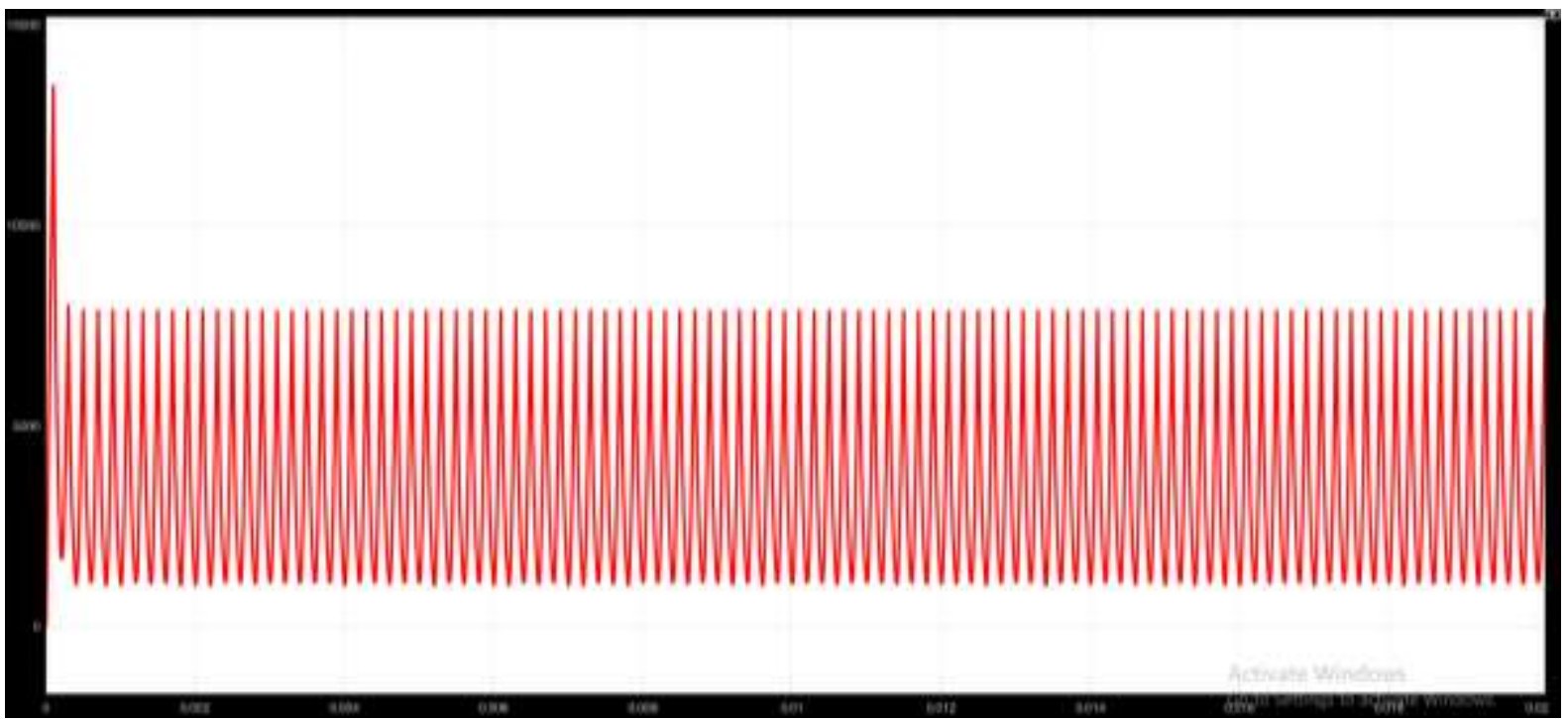

Fig -13: Output Power

\section{CONCLUSION}

After modelling of solar PV system a fuzzy logic control system has been proposed by referring to the conventional algorithms and nonlinear characteristics of photovoltaic. The uncertain conditions has been provided to the PV module for testing the uncertain conditions due to weather. As we can see in the result the DC link voltages are constant and the output power is almost constant throughout the time which is an important factor so that it can be supplied to the converters and after that it may be supplied to the load or grid then we can get smooth output voltage waveform. As compared to the conventional P \& O method the fuzzy logic based MPPT optimises the operating power of the system with better performance. Many research is going on this field to improve MPPT and we can also work for some other rule table based on different parameters to improve the output performance with the different climatic conditions. 


\section{REFERENCES}

[1] Murtaza Marcello AF, Filippo, Tabrez U, Boero D, DeGiuseppe. 2017. MPPT technique based on improved evaluation of photovoltaic parameters for uniformly irradiated photovoltaic array. Electric Power Systems Research. 145: 248-263.

[2] Raseswari Pradhan, Bidyadhar Subudhi. 2012. A steepest-descent based maximum power point tracking technique for a photovoltaic power system, 2nd International Conference on Power, Control and Embedded Systems (ICPCES).

[3] Dehghanzadeh A, Farahani G, Maboodi M. 2017. A novel approximate explicit double diode model of solar cells for use in simulation studies. Renewable Energy. 103: 468-477.

[4] Ru-Min Chao, Shih-Hung Ko, Hung-Ku Lin and I-Kai Wang. 2018. Evaluation of a Distributed Photovoltaic System in Grid-Connected and Standalone Applications by Different MPPT Algorithms. Energies.11: 1484-1485.

[5] Kislovski A, Redl R. Maximum power tracking using positive feedback. 1994. 25th Annual IEEE International Proceedings of the power electronics specialists conference.2:1065-1068.

[6] Pan C-T, Chen J-Y, Chu C-P, Huang Y-S. 1999. A fast maximum power point tracker for photovoltaic power systems. International Proceedings of the industrial electronics society. 1: 390-393.

[7] Yoash Levron and Doron Shmilo vitz. 2013. Maximum Power Point Tracking Employing Sliding Mode Control. IEEE Transactions on Circuits and Systems-I: 60(3):724-732.

[8] Noguchi T., and H. Matsumoto. 2003. Maximum Power Point Tracking Method of Photovoltaic Using Only Single Current Sensor. Proceedings of 10th European conference on power electronics and applications.

[9] T. Esram, J. W. Kimball, P. T. Krein, P. L. Chapman, and P. Midya. 2006. Dynamic maximum power point tracking of photovoltaic arrays using ripple correlation control. Transactions Power Electronics. 21(5):1282-1291.

[10] C.-C. Wang, M.-C. Wu, S.-Y. Ou, K.-J. Lin and C.-R. Lin. 2010. Analysis and research on maximum power point tracking of photovoltaic array with Fuzzy Logic Control and Three-point Weight Comparison Method. Science China Technological Sciences. 53(8):2183-2189

[11] Ravi A, Murugan S, Danielsathiyaraj J, Aandal R "A fuzzy logic controlled solar power generation with integrated maximum power point tracking using multi-level inverter" international journal of applied engineering research 10 (14), 2315-2326,2019.

[12] Ravi. A Manoharan. P.S "Closed loop control of Diode Clamped Multilevel Inverter with Integrated Maximum Power Point Tracking for Grid Connected Photovoltaic Application" PRZEGLĄD ELEKTROTECHNICZNY, NR 10/2013.

[13] Dr. Abhishek Verma, Devendra Kumar, ““Modelling And Analysis Of Wind Energy System Connected With Grid And Total Harmonic Distortion Evaluation Based On Different Condition And Filter Configuration"," i manager journal, November - January 2021 issue (Volume No. 8, Issue No. 4) of i-manager's Journal on Power Systems Engineering (JPS).

[14] Abhishek Verma, Dr. Anup Mishra "Analysis and Simulation of solar PV connected with grid accomplished with Boost Converter and PWM based Inverter" International Journal of Trend in Scientific Research and Development (IJTSRD)

[15] Askarzadeh A, Rezazadeh A. 2013. Extraction of Maximum Power Point in Solar Cells Using Bird Mating Optimizer-Based Parameters Identification Approach. Solar Energy.90: 123-133.

[16] CR Sullivan, MJ Powers. 1993. A High-Efficiency Maximum Power Point Tracker for Photovoltaic Arrays in a Solar-Powered Race Vehicle. 24th Annual IEEE International Power Electronics Specialists Conference, PESC '93. 574-580.

[17] Prasanth Ram J, Sudhakar Babu T, Rajasekar N.A.2017. Comprehensive Review on Solar PV Maximum Power Point Tracking Techniques. Renewable and Sustainable Energy Reviews. 67: 826-847. 